\title{
EFFECT OF INTERNSHIP EXPERIENTIAL LEARNING ON STUDENTS' ACADEMIC ACHIEVEMENT IN UTILIZATION OF MODEL OFFICE TECHNOLOGIES IN FEDERAL COLLEGES OF EDUCATION IN SOUTH- SOUTH, NIGERIA
}

\section{Prof. Okolocha Comfort C. and Benstowe Felicia Seledi}

\author{
${ }^{1}$ Department of Technology and Vocational Education, Nnamdi Azikiwe University, Akwa, \\ Anambra State. \\ ${ }^{2}$ Federal College of Education (Tech.), Omoku, Rivers State
}

Cite this article:

Okolocha C.C., Benstowe F.S. (2021), Effect of Internship Experiential Learning on Students' Academic

Achievement in Utilization of Model Office Technologies in Federal Colleges of Education in South-South, Nigeria. British Journal of Education, Learning and Development Psychology 4(1), 76-89. DOI: 10.52589/BJELDPVFXPY4ND.

\section{Manuscript History}

Received: 28 April 2021

Accepted: 18 May 2021

Published: 12 June 2021

Copyright $(\odot) 2020$ The Author(s). This is an Open Access article distributed under the terms of Creative Commons AttributionNonCommercial-NoDerivatives 4.0 International (CC BY-NC-ND 4.0 ), which permits anyone to share, use, reproduce and redistribute in any medium, provided the original author and source are credited.
ABSTRACT: This study determines the effect of internship experiential learning on students' academic achievement in utilization of model office technology in Federal Colleges of Education in southsouth, Nigeria. Two specific purposes, two research questions and two hypotheses were posed to guide the study. Quasi-experimental research design with pretest, post-test, non-randomized groups was adopted. 86 N.C.E. Ill business education (OTME) students during the 2018/2019 academic session made up the population. The sample consisted of 45 and 41 N.C.E. III Business Education (OTME) students from Federal College of Education (Tech.), Asaba and 41 OTME students from Federal College of Education (Tech.), Omoku, Rivers State. Purposive sampling technique was used to select the sample for study. A rating scale questionnaire was used for determining the students' academic achievement in model office technologies utilization. The instrument was validated by three lecturers from Faculty of Education, Nnarndi Azikiwe University Awka, Anambra State. The rating scale was subjected to reliability of stability using test-retest method to obtain r-value of 0.90. Data collected were analysed using descriptive statistics of mean scores to answer research questions one. Independent t-test was used to test null hypotheses at 0.05 level of significance. All data were computed using Statistical Package for Social Science (SPSS) version 0.16. The findings revealed those exposed to model office technologies using internship experiential learning scored higher than those in control group. The findings also revealed that both male and female benefited from internship experiential learning activities used for teaching model office technologies. In same vein, the results revealed significant difference in the academic scores of experimental as against that of control group. Based on the findings, it was recommended among others that Business education (OTME option) lecturers should try as much as possible to adopt, design and implement internship experiential learning when handling any course that has to do with model office technologies utilization in order to assist students to acquire the needed practical skills content.

KEYWORDS: Instructional Strategy, Experiential Learning, Academic Achievement Score 


\section{INTRODUCTION}

The effective development of every educational programme beneficiary's behaviour and understanding to a large extent depends on several factors. These factors include but not limited to the curriculum content, learning environment, instructional strategies used by teachers, instructional materials employed, students' readiness and interest, among others (Abdulkarim, 2018). Amongst these factors, instructional strategies used by teachers for promoting effective learning, should be the concern of every educator. This is because it is through the appropriate use of instructional strategies that teachers assist their students to acquire adequate knowledge, skills and attitude for future endeavours.

Instructional strategies according to Justin (2014), are set of techniques teachers use to assist students to learn. The author further noted that instructional strategies inform the approach the teachers may take to achieve pre-determined learning objectives. Gayla (2015) noted that instructional strategies are classified as: direct, indirect, interactive, experiential, or independent. The author explained that each of these strategies differ in their effectiveness with regards to knowledge, skills and attitude development. For instance, direct instructional strategy is said to be teacher-centered and highly effective when it comes to content knowledge acquisition in any course (Abdulkarim, 2018), but highly ineffective when it comes to adequate skills and attitude development (Gayla, 2015). For the purpose of simultaneous knowledge, skills and attitude development in any course, Abdulkarim (2018) noted that there is need for teachers to adopt, design and utilize approaches that support indirect, interactive or experiential instructional strategy.

Experiential instructional strategy as one of the strategies that support simultaneous knowledge, skills and attitude development is the interest area of this study. Ashley (2014) opined that experiential instructional strategy is concerned with connecting real life practices to learning through the process of reflection. The author noted that the philosophy of experiential instruction is based on the saying of Confucius that "What I hear, I forget, What I see, I remember, What I do, I understand". This strategy when utilized promotes experiential learning experiences through real-life activities a shift from the teacher-centred lecture method mostly used in tertiary institutions to deliver courses. Thus, experiential learning approach is more of a student-centred approach. In the words of Ashley (2014), there are five different experiential learning approaches that can be used by educators to provide students with experience-based learning. The experiential learning approaches as outlined by the author are: active based experiential learning, problem-based experiential learning, project-based experiential learning; service based experiential learning and internship based experiential learning. Of all these approaches, the interest of the researcher of this present study centres on internship experiential learning because of the ample opportunity it gives to both teacher and the students to interact with the real world of work.

Internship experiential learning according to Wurdinger and Carlson (2010) is considered a very important approach in assisting students to get exposed to their career related work experience because it places learners on on-the-job training. The American Psychological Association Commission on Accreditation (APACA, 2005) also opined that internship experiential learning approach provides students with advanced training related to fieldwork and allows them to gain extensive real-work experience. Thus, internship experiential learning approach can be used to bridge the gap between theory and practice if properly 
utilized when implementing Office Technology and Management Education (OTME) course content.

The acquisition of knowledge and skills of model office technologies is one of the requirements for graduating holders of Nigerian Certificate in Education (NCE) in Business education from colleges of education in Nigeria (National Commission for Colleges Education, (NCCE), 2012). According to Ihmeideh (2009), model office technologies are devices and software used in the office to facilitate productivity of office workers. Abdulkarim, Odili and Princewill (2013) noted that specific model office technologies required by the minimum standard for business education programme in colleges of education are: duplicating machines, photocopiers, manual typewriters, computer and its application software, scanner, internet and adding and listening machines. Fadare in Okoro (2016) opined that to equip business education students especially those of Office Technology and Management Education (OTME) option with adequate knowledge and skills to function effectively in this $21^{\text {st }}$ century world of work, there is need to expose them to the knowledge and skills of model office technologies. The author explained that such knowledge and skills must enable the students to effectively utilize computer, electric and electronic typewriters, photocopiers, fax machine, word processors, printers, scanners, modems, electronic mail, internet and any other emerging new office technology. Thus, students are required to be exposed and tested on model office technologies such as telephones, fax machines, internet facilities, word processor, computers and application software, duplicating machines, photocopiers, shredding machine and scanning (NCCE, 2012).

Students' academic achievement is concerned with their learning outcomes in line with predetermined objectives. Supporting this, Nwalado and Oru (2016) described students' academic achievement as learning outcomes which include the knowledge, skills and experiences acquired in and outside-classroom activities. Students' academic achievement can be ascertained by measuring the knowledge, skills or experiences acquired through classroom and outside classroom activities. In this study, students' academic achievements relate to their ability in using model office technologies through instructional approaches that support outside classroom activities. This is due to the fact that the lack of or inadequacy of model office technologies in model offices of business education programme can affects their future academic achievement in model office technologies utilization (Amahi and Ogben, 2014). The authors recommended the use of excursion to offices where new model office technologies can be found in order to bridge the gap between classroom theory and practices. Ashley (2014) also suggested the use of internship experiential learning in facilitating the acquisition of knowledge and skills related to model office technologies due to its economical and efficient solution to the inadequacy of model office technologies. The author explained that this is because internship experiential learning guarantees the attachment of students to relevant organizations where they can learn how to use the appropriate model office technologies not available in their institutions of learning.

Students' academic achievements in model office technologies are not only influenced by the instructional strategy utilized by educators. The gender of students may also affect the way they learn and their future academic achievement. This is because students react differently to learning activities on the basis of their gender and learning environment. Some researchers have discovered that female students learn better in real-life learning activities 
ISSN: 2682-6704

than their male counterpart while others discovered no significant difference in the academic achievement of students in real-life learning activities on the basis of gender. For instance, Ekeyi (2013) also found a significant difference in favour of the female students taught with real-life activities as against their male counterparts in real-life activities. However, Onwukwe and Ezemoyih (2012) found a non-significant difference in the mean scores of male and female students taught accounting using electronic media such as excel. Thus, the need to examine the academic achievement of students in model office technologies on the basis of gender difference in real-life learning activities cannot be overemphasized.

Many researchers have focused their attention on the one aspect of internship learning approach or the other. For instance, Robert (2011) conducted a study to examine the relationship between business internship and students' retention, academic performance and degree of completion in the University of Cincinnati, Ohio, United State. The results of the study showed that internship has a greater impact on students' academic performance measured by improved GPA scores, students who took internship are more likely to graduates on time and internship has a positive impact on retention. Abdulkarim and Nwokocha (2012) carried out a study on the use of lecture method and experiential learning activities to develop meaningful life-long skills and entrepreneurial spirit among students in business education practicum class. The findings of the study showed that students developed multiple business skills such as: creativity skills, communication skills, interpersonal skills, thinking skills, problem-solving skills and management skills due to the experiential learning activities. Thilakerathne and Madurapperuma (2014) conducted an examination of accounting internship on subsequent academic performance. The results of the study showed a statistically-significant better performance of internship student as measured by their average marks. The results also showed that gender was negatively correlated with the students' performance which signals that male students performed better than female students. Okafor (2014) conducted a study on the effect of Kolb's 4- stage cycle model of experiential learning on students' performance and interest in vegetable crop production. The results from the analysis done revealed that Kolb's 4-Stage Cycle Model of Experiential Learning was an effective tool that improved students' performance, enhanced their ability and aroused their interest in practical Agriculture. It would be realized that not all these studies were conducted in Nigeria. In addition, to the best of the researcher's knowledge, there is no evidence of quasi-experimental research within Rivers State, Nigeria examining the effect of internship experiential learning and gender on students' academic achievement in model office technology in colleges of education.

\section{Statement of the Problem}

Business education (OTME option) as an integral part of general education is designed to equip the recipients with knowledge, skills and competencies needed in the world of work to functions as competent information managers. To achieve this aim, the minimum standard for Business education programme in Colleges of Education requires that NCE III OTME option students should be exposed and tested in the use of model office technologies and their management. This is to make them competent in mode 1 office technologies operations. Unfortunately, in Federal College of Education (Tech.), Omoku-Rivers State, Nigeria, the specific model office technologies stated in the minimum standard for this purpose are not adequately available. Considering this situation, many Business educators resort to using demonstration method in exposing the students to model office technologies in groups with 
no or little opportunity for students' demonstration on how to operate the available model office technologies. This has significantly affected the ability of the students to effectively utilize the available model office technologies. This inability of the students will have spillover effect on the overall academic achievement of the students since their scores in model office technologies utilization is to form part of their continuous assessment which is a component of their total scores in BES 327.

Although internship experiential learning provides students with opportunity to learn how to use some of the model office technologies not available in schools but available in world of work, there seem to be no available literature showing the effect of internship experiential learning and gender on students' academic achievement in model office technologies in colleges of education. It is to provide empirical evidence on the effect of internship experiential learning and gender on students' academic achievement in model office technologies in Federal College of Education (Tech.), Omoku - Rivers State, Nigeria that the present study was conducted.

\section{Purpose of the Study}

The major purpose of this study is to determine the effect of internship experiential learning on students' academic achievement in model office technology in in Federal College of Education (Tech.), Omoku - Rivers State, Nigeria. Specifically, the study seeks to determine the:

1. Difference in academic achievement mean scores of students exposed to model office technologies using internship experiential learning as against those exposed to demonstration method

2. difference in academic achievement mean scores of male students exposed to model office technologies using internship experiential learning as against their female counterpart

\section{Research Questions}

The following research questions guided the study:

1. What is the difference in academic achievement mean scores of students exposed to model office technologies using internship experiential learning as against those exposed to demonstration method?

2. What is the difference in academic achievement mean scores of male students exposed to model office technologies using internship experiential learning as against their female counterpart?

\section{Hypotheses}

The following hypotheses were tested at 0.05 level of significance:

1 There is no significant difference in the academic achievement mean scores of male and female students exposed to model office technologies using internship experiential learning. 
3 The interactive effect of internship experiential learning and gender on the academic achievement mean scores of students exposed to model office technologies is not significant.

\section{THEORETICAL FRAMEWORK}

\section{Experiential Learning Theory (ELT) by David A. Kolb (1984)}

Experiential Learning Theory (ELT) was propounded by David A. Kolb 1984. This theory states that learning is created through the transformation of experience(s). In other words, learning is facilitated through the continuous reconstruction of experiences. The ELT requires the students to use both their cognitive, psychomotor and affective domains abilities in feeling, thinking, perceiving and practicing the tasks related to the topic under consideration in order to refine their knowledge and skills. This theory is related to the present study because it provides the basis for the design of the internship approach utilized in this study. The approach to be experimented in this study would therefore ensure that students are given the opportunity of experiencing how to utilize the various model office technologies.

\section{Method}

This study adopted quasi-experimental research design with pretest, post-test, nonrandomized groups. This research design is deemed appropriate for the study because it assisted the researcher in determining the effect of the independent variable on dependent variables. The design is diagrammatically represented as:

$$
\begin{array}{llll}
\text { Control group: } & \mathrm{O}_{1} & & \mathrm{O}_{1} \\
\text { Experimental group } & \mathrm{O}_{2} & \mathrm{X} & \mathrm{O}_{2}
\end{array}
$$

Where: X represents treatments (internship experiential approach)

The population of the study consisted of 86 N.C.E. Ill business education (OTME) students during the 2018/2019 academic session made up the population. The NCE III students were selected as the target population of this study because they have become stabilized and familiar with the system and are required to take Office Technology and Management Education course in the second semester with emphasis on the minimum standard on the practical utilization of model office technologies in the model office. The sample consisted of 45 and 41 N.C.E. III Business Education (OTME) students from Federal College of Education (Tech.), Asaba and 41 OTME students from Federal College of Education (Tech.), Omoku, Rivers State. Purposive sampling technique was used to select the sample for study. The purposive sampling technique was used to select sample based on the following specific criteria: (1) the students were not placed in a business centre or any other private organization where there are model technologies during 2017/2018 SIWES programme. (2) the student attended weeks of lectures in office technology and management course. 
Two sets of instruments were developed by the researcher for the purpose of this study. These include an instructional package for model office technologies utilization and an observational checklist for model office technologies utilization to test the students' academic achievement. The instruments were tagged: Model Office Technologies Utilization Instructional Packages (MOTUIPs) and Model Office Technologies Utilization Observational Checklist (MOTUOC).

\section{Responses}

Very Well Performed (VWP)

Well Performed (WP)

Poorly Performed (PP)

Unable to Performed (UPP)

\author{
Rating Scale \\ 4points \\ 3 points \\ 2points \\ 1point
}

The instrument was subjected to face and content validation. The reliability of MOTUOC was ascertained using test-retest method. The test-retest method was used to test the stability of the instrument in measuring what it wants to measure. The test-retest was done in an interval of two weeks using a group of 15 NCE III Business Education (OTME) students from FCE, Obudu during 2018/2019 who were not used for the study. The correlation between the two administrations was computed using Statistical Package for Social Science (SPSS) to obtain $r$ - value of Pearson Product Moment Correlation Coefficient (PPMC) of 0.90 . The $r$ value of 0.90 was converted to reliability coefficient using the spearman rho prophetic formula to obtain a reliability index of 0.76 .

The data collected for the study were analysed using descriptive statistics of mean scores to answer the five research questions. The Analysis of Variance (ANOVA) was used to test one of the null hypotheses while the t-test statistics was used to test the remaining null hypothesis. All computations were done with the aid of Statistical Package for Social Science (SPSS) version 16.0. The null hypotheses were accepted where $\mathrm{p}$ value of the calculated t-test is greater than or equal to 0.05 level of significance. Otherwise, they were rejected.

\section{RESULTS/DISCUSSION}

\section{Research question 1}

What is the difference in academic achievement mean scores of students exposed to model office technologies using internship experiential learning as against those exposed to demonstration method? 
Table 1: Summary of Students' Academic Achievement Mean Scores in Model Office Technology in Demonstration Group and Internship Experiential Learning Group. $\mathbf{n}_{1}$ $=45, n_{2}=41$

\begin{tabular}{|c|c|c|c|c|c|c|c|}
\hline \multirow[t]{2}{*}{$\mathbf{S} / \mathbf{N}$} & \multirow[t]{2}{*}{$\begin{array}{l}\text { Model Office } \\
\text { Technology }\end{array}$} & \multicolumn{3}{|c|}{ Demonstration Group } & \multicolumn{3}{|c|}{$\begin{array}{l}\text { Internship Experiential } \\
\text { Learning Group }\end{array}$} \\
\hline & & $\begin{array}{c}\text { Pre- } \\
\text { test } \\
\text { Mean }\end{array}$ & $\begin{array}{c}\text { Post- } \\
\text { test } \\
\text { Mean }\end{array}$ & $\begin{array}{l}\text { Mean } \\
\text { diff. }\end{array}$ & Pre-test & Post-test & $\begin{array}{c}\text { Mean } \\
\text { diff }\end{array}$ \\
\hline 1. & $\begin{array}{l}\text { Computer word } \\
\text { processing package. }\end{array}$ & 10.8 & 14.04 & 3.24 & 11.39 & 17.61 & 6.22 \\
\hline 2. & Duplicating Machine & 6.47 & 15.24 & 8.77 & 6.78 & 18.68 & 11.9 \\
\hline 3. & Photocopier & 6.71 & 13.78 & 7.07 & 7.46 & 17.54 & 10.08 \\
\hline 4. & Scanner & 7.00 & 14.38 & 7.38 & 6.66 & 16.37 & 9.71 \\
\hline 5. & Spiral Binding Machine & 5.82 & 12.4 & 6.58 & 6.14 & 15.07 & 8.93 \\
\hline 6. & $\begin{array}{l}\text { Printer } \\
\text { Mean Scores }\end{array}$ & $\begin{array}{l}8.00 \\
7.46\end{array}$ & $\begin{array}{l}14.29 \\
\mathbf{1 4 . 0 2}\end{array}$ & $\begin{array}{l}6.29 \\
6.56\end{array}$ & $\begin{array}{l}8.66 \\
7.85\end{array}$ & $\begin{array}{l}15.98 \\
\mathbf{1 6 . 8 7}\end{array}$ & $\begin{array}{l}7.32 \\
\mathbf{9 . 0 2}\end{array}$ \\
\hline
\end{tabular}

Table 1 shows students exposed to model office technologies using demonstration method had mean achievement score of 7.46 in pre-test and 14.02 in post-test making mean difference in the control group in favour of post-test of 6.56. On the other hand, those exposed to model office technologies using internship experiential learning approach had mean achievement scores of 7.85 in pre-test and 16.87 in post-test making mean difference in the experimental group in favour of post-test of 9.02. In addition, when the mean achievement scores of post-test of the control group and the experimental group are compared, there is a mean achievement score difference of 2.85 in favour of the experimental group. This means that exposing students to model office technologies using internship experiential learning approach increased their academic achievement mean scores.

\section{Research question 2}

What is the difference in academic achievement mean scores of male students exposed to model office technologies using internship experiential learning as against their female counterpart? 
Table 2: Summary of Male and Female Students' Academic Achievement Mean Scores in Model Office Technology in Internship Experiential Learning Group. $n_{1}=19, n_{2}=$ 22

\begin{tabular}{|c|c|c|c|c|c|c|c|}
\hline \multirow[t]{2}{*}{$\mathbf{S} / \mathbf{N}$} & \multirow[t]{2}{*}{$\begin{array}{l}\text { Model Office } \\
\text { Technology }\end{array}$} & \multicolumn{3}{|c|}{$\begin{array}{c}\text { Male Internship } \\
\text { Experiential Learning } \\
\text { Group }\end{array}$} & \multicolumn{3}{|c|}{$\begin{array}{c}\text { Female Internship } \\
\text { Experiential Learning } \\
\text { Group }\end{array}$} \\
\hline & & $\begin{array}{l}\text { Pre-test } \\
\text { Mean }\end{array}$ & $\begin{array}{l}\text { Post- } \\
\text { test } \\
\text { Mean }\end{array}$ & $\begin{array}{c}\text { Mean } \\
\text { diff. }\end{array}$ & $\begin{array}{l}\text { Pre-test } \\
\text { Mean }\end{array}$ & $\begin{array}{l}\text { Post- } \\
\text { test } \\
\text { Mean }\end{array}$ & $\begin{array}{l}\text { Mean } \\
\text { diff. }\end{array}$ \\
\hline 1. & $\begin{array}{l}\text { Computer word } \\
\text { processing package. }\end{array}$ & 11.05 & 17.84 & 6.79 & 11.68 & 17.41 & 5.73 \\
\hline 2. & Duplicating Machine & 6.58 & 18.53 & 11.95 & 6.96 & 18.82 & 11.86 \\
\hline 3. & Photocopier & 7.16 & 17.32 & 10.16 & 7.73 & 17.73 & 10.00 \\
\hline 4. & Scanner & 6.47 & 16.11 & 9.64 & 6.82 & 16.59 & 9.77 \\
\hline 5. & Spiral Binding Machine & 5.95 & 14.95 & 9.00 & 6.32 & 15.18 & 8.86 \\
\hline 6. & $\begin{array}{l}\text { Printer } \\
\text { Mean Scores }\end{array}$ & $\begin{array}{l}8.95 \\
7.69\end{array}$ & $\begin{array}{l}15.84 \\
\mathbf{1 6 . 7 7}\end{array}$ & $\begin{array}{l}6.89 \\
\mathbf{9 . 0 8}\end{array}$ & $\begin{array}{l}8.41 \\
7.99\end{array}$ & $\begin{array}{l}16.09 \\
16.97\end{array}$ & $\begin{array}{l}7.68 \\
\mathbf{8 . 9 8}\end{array}$ \\
\hline
\end{tabular}

Table 2 shows male students exposed to model office technologies using internship experiential learning had mean achievement score of 7.69 in pre-test and 16.77 in post-test making mean difference in favour of post-test of 9.08. On the other hand, female students exposed to model office technologies using internship experiential learning approach had mean achievement scores of 7.99 in pre-test and 16.97 in post-test making mean difference in favour of post-test of 8.98. In addition, when the mean achievement scores of post-test of the control group and the experimental group are compared, there is a mean achievement score difference of 0.20 in favour of the female in experimental group. Nevertheless, it must be noted that the male students in the experimental group gain more when their pre-test and post-test are compared. The results indicated that exposing both gender to model office technologies using internship experiential learning approach increased their academic achievement mean scores. However, the female students outperformed their male counterpart.

Hypothesis 1: There is no significant difference in the academic achievement mean scores of students exposed to model office technologies using internship experiential learning as against those exposed to demonstration method. 
Table 3: Summary of t-test Analysis of Academic Achievement Mean Scores of Students Exposed to Model Office Technology Using Demonstration Method as Against Internship Experiential Learning

\begin{tabular}{|c|c|c|c|c|c|c|c|}
\hline Variable & $\mathbf{N}$ & Mean & $\begin{array}{c}\text { Std. } \\
\text { Deviation }\end{array}$ & df & $\begin{array}{c}\text { Std } \\
\text { Error }\end{array}$ & $\mathbf{t}$ & $\begin{array}{c}\text { Sign for } 2 \\
\text { tailed }\end{array}$ \\
\hline $\begin{array}{l}\text { Demonstration } \\
\text { method }\end{array}$ & 45 & 14.02 & 0.94 & & & & \\
\hline $\begin{array}{l}\text { Internship } \\
\text { Experiential } \\
\text { Learning } \\
\text { Approach }\end{array}$ & 41 & 16.88 & 1.31 & 84 & 0.83 & -11.53 & 0.0001 \\
\hline
\end{tabular}

Table 3 shows $\mathrm{t}=-11.53, \mathrm{df}=84, \mathrm{p}<0.05$ at 0.0001 . Therefore, since $\mathrm{p}$ value calculated at 2 -tailed test of 0.0001 is less than the p-value provided at 0.05 , the null hypothesis is rejected. Therefore, it means that there is significant difference in the academic achievement mean scores of students exposed to model office technologies using internship experiential learning as against those exposed to demonstration method.

Hypothesis 2: There is no significant difference in the academic achievement mean scores of male and female students exposed to model office technologies using internship experiential learning.

Table 4: Summary of t-test Analysis of Academic Achievement Mean Scores of Female and Male Students Exposed to Model Office Technology Against Internship Experiential Learning

\begin{tabular}{lccccccc}
\hline Variable & N & Mean & Std. Deviation & df & Std Error & t & $\begin{array}{c}\text { Sign for 2 } \\
\text { tailed }\end{array}$ \\
\hline $\begin{array}{l}\text { Demonstration } \\
\text { method }\end{array}$ & 19 & 16.77 & 1.35 & & & & \\
$\begin{array}{l}\text { Internship } \\
\begin{array}{l}\text { Experiential } \\
\text { Learning } \\
\text { Approach }\end{array}\end{array}$ & 22 & 16.97 & 1.29 & & & & \\
\hline
\end{tabular}

Table 4 shows $\mathrm{t}=-4.78, \mathrm{df}=39, \mathrm{p}<0.05$ at 0.03 . Therefore, since $\mathrm{p}$ value calculated at 2 tailed test of 0.0001 is less than the p-value provided at 0.05 , the null hypothesis is rejected. Therefore, it means that there is significant difference in academic achievement mean scores of male and female students exposed to model office technologies using internship experiential learning. 


\section{DISCUSSION OF FINDINGS OF THE STUDY}

The findings of the study showed that there was a difference in the academic achievement mean scores of students exposed to model office technologies using internship experiential learning as against those in demonstration method group. The difference is in favour of students in internship experiential learning. The results also showed that there was a significant difference in the academic achievement mean scores of students exposed to model office technology in favour of students in internship experiential learning as against those in demonstration method group. The differences in the academic achievement mean scores of the students could have emanated from the fact that students in internship experiential learning group enjoyed the co-knowledge creation effect of internship experiential learning as they interact with experts who have been using the model office technologies in their place of placement which the demonstration group students are not opportuned to enjoy. In addition, the differences in favour of the students in the internship experiential learning group must have occurred as a result of the fact that they learnt about the model office technologies in an environment where such technologies were frequently utilized for performing jobs while the students only used it once for the purpose of learning. This means that the frequent utilization of the model office technology by those in the experiential learning group aided their academic achievement scores. Supporting these facts, O'Toole (2007) supported opined that students in internship are given the opportunity to learn by doing where they can find mentors to guide them during the internship. Although, demonstration method also allows for mentors to guide students, internship experiential learning provides a more knowledge co-creation environment than demonstration method. Kolb (1984) supported this fact when the author noted that knowledge sharing in experiential learning environment assists learners to perform better in subsequent related tasks. The findings of this study are in line with that of Gomez, Lush and Clements (2004) who discovered that students who undergo internship performed better than normal students. It is also in line with the findings of Reddy and Moores (2006) who noted that internship significantly improved the scores of students. It is also in line with the findings of Robert (2011) which showed that internship has a greater impact on students' academic performance. It is also in line with the findings of Thilakerathne and Madurapperuma (2014) who noted that internship has a positive impact on students' achievement scores in subsequent academic course work. The findings are contrary to the observations of Wilson (2004) that demonstration method has no substitute when it comes to helping students to learn the proper techniques of handling technologies.

The findings of the study showed that there was a difference in the academic achievement mean scores of male and female students exposed to model office technologies in internship experiential learning group. The results also showed that there was no significant difference in the academic achievement means scores of female and male students exposed to model office technologies using internship experiential learning. This shows that even though there was a difference in their academic achievement mean scores, the difference was not significant. The reason for the insignificant difference in the academic achievement mean scores of female and male students may have to do with the fact that both gender were exposed to the same kind of placement, they all have access to expert advices, and they both learn in an internship experiential learning environment that gave them the opportunity to carry out real-life tasks using the model office technologies available. 
The findings of this study are contrary to the findings of Robert (2011) who found out that male students showed a greater increase in GPA post-internship than did female students. It is also contrary to the assertion of Agboola (2006) who noted that because male students have less anxiety for Information and Communication Technology (ICT) devices and their use, they exhibit a higher degree of mastery in their utilization more than female students. This result also showed that rather than limit female students' ability to scoring higher on essays and other forms of written evaluations as noted by Abdulkarim (2014), the female students also have the ability to attain higher academic achievement in model office technologies utilization if exposed to internship experiential learning.

\section{CONCLUSIONS}

Sequel to the findings of this study, it can be concluded that internship experiential learning approach is superior to demonstration method when it comes to assisting learners to learn the operations of model office technologies in an authentic and challenging environment. This is because the students exposed to model office technologies using internship experiential learning approach had academic achievement scores that were higher than that of those exposed to office technologies using demonstration method. It can also be concluded that both female and male students gained more from internship experiential learning.

\section{Implications of the Study}

The findings of this study have certain implications. These implications are discussed as follows:

Educational Implications: in order to simulate the desire of lecturers to utilize out-ofclassroom approach such as internship experiential learning to facilitate students learning of model office technology, there is need to organize seminar and workshop for lecturers on how to use, design and implement internship experiential learning approach for learning model office technologies in colleges of education, Nigeria.

\section{Recommendations}

Based on the findings of the study, the conclusions drawn and the implications of the findings, the following recommendations are put forward:

1. Administrators of the business Education programme (OTME option) in colleges of education should organize seminars and workshops for lecturers saddled with the implementation Office Technology and Management Education course content on how to design and implement internship experiential learning programme plan.

2. Business education (OTME option) lecturers should try as much as possible to adopt, design and implement internship experiential learning when handling any course that has to do with model office technologies utilization in order to assist students to acquire the needed practical skills content. 
British Journal of Education, Learning and Development Psychology

ISSN: 2682-6704

Volume 4, Issue 1, 2021 (pp. 76-89)

www.abjournals.org

3. Curriculum planners of the business education programme (OTME option) should make provision for at least four credit hours for courses related to model office technology utilization in order to enable students to go for two hours internship after two hours content knowledge acquisition weekly.

\section{REFERENCE}

Abdulkarim, M. \& Nwokocha, E. G. (2012). Using lecture and experiential learning activities to develop meaningful life-long skills and entrepreneurial spirit among students of business education practicum class. International Journal of Innovation in Management Science. 4 (1). 72 - 77

Abdulkarim, M. (2014). PowerPoint packages utilization and students' academic performance in economics in senior secondary schools in Rivers State. An unpublished dissertation submitted to the university of Uyo-Akwa Ibom State for the award of Msc. Ed. Business Education.

Abdulkarim, M. (2018). Experiential instructional approaches and entrepreneurial skills acquisition among business education students in Federal College of Education (Tech.), Omoku - Rivers State. An unpublished thesis submitted to the University of Uyo-Akwa Ibom State for the award of Ph.D in Business Education.

Amahi, F. U. \& Ogben, F. (2014). Making global workers out of business education graduates through the inclusion of new technologies in a competence based harmonized curriculum. Nigerian Journal of Business Education. 1 (3). 72 - 81

Ashley, G. (2014). Experiential learning, rationale, approaches and implication for practice in events management and hospitality courses. Investigation in University Teaching and Learning. 9 (Spring, 2014). 8 - 14

Ekeyi, D. N. (2013). Effect of demonstration method of teaching on students' achievement in agricultural science. World Journal of Education. 3 (1). 1 - 7

Gayla, S. K. (2015): Instructional approaches. Retrieved online from www.teachinglearningresources.pbworks.com on $18^{\text {th }}$ April, 2018

Justin, D. (2014): Principles of teaching, different methods and approaches. Instructional characteristics blog: Retrieved Online from www.slideshare.net on $20^{\text {th }}$ March, 2017

Kolb, D. A. (1984). Experiential Learning: Experience as the Source of Learning and Development. Englewood Cliffs, New Jersey: Prentice-Hall.

National Commission for Colleges of Education (NCCE, 2012). Minimum standards for Nigeria certificate in education in vocational and technical education. Abuja. TETFUND project.

O'Toole, K. (2007), Assessment of experiential learning; the case of public policy internship. Educational Research and Perspective. 34 (2). 51 - 62

Okafor, N. B. (2014). Effect of Kolb's 4-stage cycle model of experiential learning on students' performance and interest in vegetable crop production in senior secondary schools in Anambra State, Nigeria. A thesis submitted for the award of Ph.D in Agricultural Education to the department of vocational teacher education, Faculty of Education, University of Nigeria, Nsukka

Onwukwe, V. \& Ezemoyih, C. M. (2012). Effects of demonstration method, electronic medica and lecture method on students' interest in accounting education. Business Education Journal. VIII (2). 280 - 289 
British Journal of Education, Learning and Development Psychology

ISSN: 2682-6704

Volume 4, Issue 1, 2021 (pp. 76-89)

www.abjournals.org

Robert, B. W. (2011). Business internship and their relationship with retention, academic performance and degree of completion. Graduate Thesis and Dissertation. Paper 12015. Retrieved online from www.lib.dr.iastate.edu/etd on 4th July, 2017

Thilakerathne, P. M. C. \& Madurapperuma, M. W. (2014). An examination of accounting internship on subsequent academic performance. International Journal of Economics, Finance and Management Sciences. 2 (1). 8 - 15 